\title{
Indonesia's Inability in Removing Self from Colonial Law (Study of Employment Laws)
}

\author{
Nur Putri Hidayah, ${ }^{1}$, Fitria Esfandiari ${ }^{2}$, Sholahuddin Al-Fatih ${ }^{3}$ \\ \{nurputri@umm.ac.id ${ }^{1}$, fit.esfan@gmail.com ${ }^{2}$, sholahuddin.alfath@gmail.com³ $\}$ \\ ${ }^{1,2,3}$ University of Muhammadiyah Malang, Malang, Indonesia
}

\begin{abstract}
When a national law came into force, the previous law made in the colonial era was concrete that the Constitution should be repealed. For example, the enactment of Law No.5 / 19960 on the Basic Terms of the Agrarian repeal the provisions of land, water and natural resources contained in Book II of the Civil law, or the operation of Law No. 1/1974 on Marriage revokes the provisions on matters relating to marriage found in the Civil Law Book. However, this is not the case with the Employment Law where provisions of Chapter VIIA of Article 1601 of the Civil Code until 1617 of the Civil Code are still in effect, until the drafting of an omnibus draft law on Work Creation, also does not invalidate the provisions of the Employment in Code Civil Law. This study aims to examine historically and conceptually whether the terms of the employment in the Code Civil Law are right or not. Research method is normative. The results show that Indonesia must break free from colonial rule and gradually establish its national law that has the philosophical basis of Pancasila. To make it happen, the revisions to Law No. 13/2003 should be done in addition to the burden of: (a) employment agreement between husband and wife, b) provision of fines accompanying compensation, c) employers 'obligation to pay wages on time, d) employers' obligation to provide employment certificates, 5) Responsibility and compensation for Outsourcing Contract.
\end{abstract}

Keywords: Colonial Law, Labor, Indonesia

\section{Introduction}

Indonesia's independence since 1945 has not made Indonesia free from colonial influence in the colonial era. A concrete example, for the rule of law in nature, to this day Indonesia still uses Colonial leave law as the Code of Civil Law [1]-[4], while the Netherlands itself has not used the Constitution we now use, since 1992 [5]. The use of this Dutch legal code is based on the principle of concordance [6] found in the transitional rules of the 1945 Constitution.

It should be understood, that the basic application of concordance should be temporary [7], given that the Netherlands differs from Indonesia in terms of culture, culture, customs, religion [8], and the geographical condition of the country. Therefore, a positive civil law that should prevail in Indonesia is a civil law that has philosophical foundations based on the views and personality of the 
people of Indonesia by providing the basic principles of justice, justice and prosperity for the benefit of every citizen, always ethical, moral and spiritual [9], [10] and certainly not the current Code of Civil Law.

In fact, the attempt to break free from concrete colonial law has been around since Indonesia's independence, evidenced by the efforts of legislative drafting to date. However, the failure was due to differences in view of the development of the law, namely whether to use national law and to abolish the colonial remnant law altogether, on the other hand many still wanted to go along with the national law[5].

Currently the master rule regarding employment is set forth in Law No. 13/2003 on Employment. But strangely enough, the existence of Law No. 13/2003 does not automatically repeal the provisions of the provisions of Chapter VIIA of Article 1601 until 1617 the Code of Civil Law, although similar colonial relics laws have been repealed. If the purpose of law making in Indonesia was to break free from colonial legal rules, then the existing provisions of the Employment Code should be adopted only in the present Employment Law, so that one of the historical reasons for establishing the Employment Law could be fulfilled. Even if it is understood to be studied further, the Employment Law in Indonesia is currently undergoing 2 revisions and 2 changes, namely: 1) Law No. 13/2003 repealed Law No. 28 of 2000, repealed Law No.11 / 1998 and Law No. 25/1997. 2) Law No. 28/2000 revised Law No. 25/1997, 3) Law No.11 / 1998 revised Law No. 25/1997, 4) Law No.25 / 1997 repealed Law No.1 / 1951.

The repeal of the existing provisions of the Civil Code, coupled with the transitional provisions of Article 191 which read "All implementing rules governing employment shall prevail to the contrary and / or have not been replaced by the new regulations under this Act" matters relating to the working conditions of the Civil Code are still in use. Why is that? Because there are provisions of the work set out in the Civil Code, but not in the Employment Law.

Previous studies have shown that Indonesia should have withdrawn from the Code of Civil Law due to many provisions that are no longer relevant to the values and development of society [5]. Indonesia was already trying to break free from colonial law, but it was not possible because of the differing views of the legislators [5], influencing the flow of colonial governmental law especially during the new era of 1973-1997 [10].

However, to date no study has examined the concept of whether the terms of the employment agreement in the code of civil law are right or wrong. It is hoped that the results of this study will help Indonesian legislators and governments determine their attitude and formulate appropriate legislation in the field of employment, thus freeing them from the shadow of colonial law.

\section{Method}

The research method used in this study is the normative method [11]. The purpose of this study is to find the answer whether or not the provisions regarding employment contained in the law code of civil law are not revoked, even though national laws on employment in Law No.13 / 2003 on Labor have been applied. The data in this article is presented descriptively and qualitatively. To answer the formulation of research problems, a regulatory approach, historical approach and conceptual approach are used so that research objectives can be answered [12]. 


\section{Discussion}

\subsection{History of Indonesian Labor Law.}

\subsubsection{Before Indonesian Independence}

The period before independence could be said to be part of the dark Indonesian period, because the Indonesian people lived during colonial times and slavery[13], [14]. To overcome this, the Netherlands issued [15] Staatblad 1817 No. 42 which contained a ban on the importation of slaves into Java, then following Regelling Regulations 1818 Article 115 which abolished slavery.

It turns out that slavery is only changing terms, but the essence (worker excitation) is the same, namely Rodi. Rodi's work in Indonesia[16] began with the cooperation of certain villages or tribes, which gradually shifted into forced labor, to serve the interests of the Dutch Indian government and its dignitaries. Because of this, a series of other regulations were endorsed to be issued such as Registration of slave children: Staatblad 1833 Number 67 and exemption from slavery for seafarers who were made slaves Staatblad 1848 Number 49.

Codification of Indonesian Civil Code was announced on April 301847 through Staatblad No. 23 and entered into force in January 1946 [17]. Previously, Code of Civil Law was a codification compiled by the Law Commission for the Dutch East Indies in 1839 [2]. The existence of CODE OF CIVIL LAW is actually not for the son's earth but for European descent and the like. In the end, Indonesia adopted the law to cover the legal vacuum and help resolve legal issues in Indonesia [5]. At Code of Civil Law, labor provisions are regulated in Articles 1601a to 1617. sla

Apart from being regulated in the Civil Code, employment is also regulated in other provisions such as the Ordinance on the Mobilization of Indonesians to Work Outside Indonesia Staatsblad Year 1887 Number 8, Ordinance dated December 17, 1925 Regulations concerning Restrictions on Child Labor and Night Work for Women (Staatsblad Year 1925 Number 647); Ordinance of 1926 Regulations concerning the Work of Children and Young People on Ships (Staatsblad Year 1926 Number 87), Ordinance dated May 4, 1936 concerning Ordinance for Regulating Activities for Prospective Workers (Staatsblad Year 1936 Number 208), and Ordinance concerning Repatriation Workers Received Or Deployed from Outside Indonesia (Staatsblad Year 1939 Number 545), and Ordinance Number 9 Year 1949 concerning Restrictions on the Work of Children (Staatsblad Year 1949 Number 8).

\subsubsection{After Indonesian Independence}

The first draft law concerning employment after Indonesian independence was Law No. 12 of 1948 concerning Work. The background to the creation of this law as a preamble to the law is that to ensure decent work and livelihoods for workers, it is necessary to establish rules regarding labor work. Matters regulated in this work law include child and young workers, female workers, work and rest periods, workplace and labor housing, employer responsibilities, criminal provisions, investigation of violations, and additional rules. Uniquely, the birth of the work law does not necessarily regulate the repeal of legislation compiled by the colonial, which 
has been in effect since before independence. In addition to this law, labor matters are also regulated separately in the following laws:

1) Law no. 33 of 1947 concerning work accidents

2) Law no. 23 of 1948 concerning labor inspection

3) Law no. 21 of 1954 concerning labor agreements between trade unions and employers

4) Law no. 22 of 1957 concerning the Settlement of Industrial Relations Disputes

5) Law no. 18 of 1956 concerning the Approval of the Convention on International Labor Organizations (ILO) No. 98 concerning the Basics of the Right to Organize and Collective Bargaining

All of these laws do not have any repeal of any labor regulations made during the colonial era. The making was gradual and not integrated in one law.

Efforts to escape from colonial law in the field of labor began to appear when entering the second millennium era, namely the issuance of Law Number 25 of 1997 concerning Labor. Based on the consideration, this Law was born in the context of national development to realize a prosperous, just, prosperous and equitable Indonesian society both material and immaterial. Another goal is to protect workers for the purpose of ensuring the basic rights of workers and ensuring equality of opportunity and treatment without discrimination to realize the welfare of workers and their families in the context of fair industrial relations. Matters regulated in this law are the Foundation, principles and objectives of its formation, equal opportunity and treatment, employment planning and information, employment relations, Pancasila industrial relations, protection, wages, welfare, service placement, foreign workers, criminal rules until the transitional regulations. The biggest portion of the regulation lies in the Pancasila industrial relations, which includes discussions on labor unions, organizing organizations, bipartite cooperation institutions, tripartite cooperation institutions, company regulations, joint labor agreements, termination of employment, termination of industrial disputes, contraction and correctional industrial relations of Pancasila.

The seriousness to break free from colonial legislation is seen in Article 198 of Law No. 25 of 1997, where the article revoked the following set of laws that were born before the independence of the Netherlands, which includes ordinances that were born since 1887, until post-independence, namely Law Number 14 of 1969 concerning Basic Provisions regarding Labor;

But because at the time of it birth reaped a lot of controversy and rejection from the workers[18], finally the following year was made changes to this law through Law No. 11/1998. The point is that the existence of Law No.11 of 1998 delayed the enactment of Law No. 25/1997 to take effect on October 1, 2000 (even though it should have been October 1, 1998). Then, in September 2000, the enactment of Law No. 25/1997 was again postponed until October 1, 2002 through a government regulation in lieu of law number $3 / 2000$.

Finally, labor provisions are currently regulated in Law No. 13/2003 on Employment. The existence of this law revokes a series of laws that were previously revoked in Law No. 28 of 2000, coupled with revoking Law No. 28 of 2000 itself. This law was born to avoid legal vacuum due to workers and employers' rejection of the PPK and PPHI Bill, the DPR and the Government agreed to revoke Law No. 25 of 1997 concerning Manpower, as well as perfecting the previous labor law. 


\subsection{Labor Regulations Regulated in the Civil Code but Not Regulated in Law No. 13/2003}

Current labor law is a law that was born that marked the era of reform and the increase in its birth did not necessarily make Indonesia as a whole free from colonial laws. Matters regulated in Chapter VIIA Article 1601 to 1617 Code of Civil Law remain in force. Whereas based on the explanation of this law, the enactment of Law 13/2003 also accommodates the provisions in the old legislation, and to revoke the provisions that are no longer in accordance with the demands and developments of the times, is also intended to accommodate very basic changes in all aspects of life the Indonesian nation with the start of the reform era at that time. So why not just accommodate the provisions contained in Code of Civil Law as accommodating this Act to the old legislation in the field of labor?

But strangely, even though it has been amended 3 times, it does not necessarily make the legislators in this case the DPR and the president think about breaking away from colonial law. This is evident from the non-regulation of several matters related to employment contained in the Civil Code, in Law No.13 / 2003, among others: first, regarding employment agreements between husband and wife. In Article 1601i of the Civil Code, it is stated that the employment agreement between the husband and wife is null and void.

Second, the fine imposed by the employer on workers must not be accompanied by compensation. In Article 1601v it is stipulated that the employer must not submit a fine as well as compensation to the worker, and if the work agreement regulates it, then the consequence is the agreement is null and void.

Third, regarding the obligation of employers to pay labor wages. Article 1602 of the Civil Code explains that employers must pay workers' wages on time, while this is not explicitly regulated in Law No.13 / 2003. Article UU No. 13 of 2003 only stipulates that employers must carry out what has been agreed in the work agreement, but does not explicitly state that the employer is obliged to pay wages at the specified time.

Fourth, regarding the obligation of employers to provide employment certificates to labor workers who no longer have a working relationship with employers. Article $1602 \mathrm{y}$ states that the employer is obliged to provide a certificate regarding the way workers fulfill their obligations and the reasons for the employment relationship to end. The certificate made by the entrepreneur must be written honestly and without lies. If the entrepreneur refuses to make or declare that is not true in the statement, then the entrepreneur must bear the losses incurred as a result. Even if an agreement is made that can eliminate or limit the obligations of the employer, the agreement is null and void. Unfortunately, the rules regarding employers' obligations to provide this employment certificate are not regulated at all in Law No. 13/2003 concerning employment.

Fifth, regarding the division of labor which actually Act No. 13/2003 also regulates this matter, but there are crucial things that are not regulated there, namely regarding work responsibilities. CODE OF CIVIL LAW regulates work responsibilities in the chartering of work and compensation both in terms of the contractor and the assignor. This is arranged to avoid greater losses at one party.

\subsection{Reasons Why Must Break Away from Colonial Law}

As a colonial product, Code of Civil Law was not formed on the basis of the nation's philosophical and personality. Personality can be interpreted as an essential nature that is reflected 
in the attitude of a person or a nation that distinguishes it from other people or nations. The nation can be interpreted as a society that together with its ancestry, customs, language and history, as well as self-government[19], [20]. The legal system of a nation cannot be separated from its human context because the law exists and is destined for human life [21]. Therefore, the law of a nation of its existence must be rooted in a socio-cultural community. It is hoped that the law that is formed based on the philosophical and personality of the nation can become a law that puts forward the basic principles of justice, truth and legal certainty. In addition, adoption of the values of the nation's philosophy can help a law and regulation be enforced more effectively and efficiently.

In addition, efforts to build a national legal system based on the philosophy of Pancasila[22] are certainly not in line with the existence and recognition of the working conditions contained in Code of Civil Law at present. Efforts to free themselves does not mean that all those contained in Code of Civil Law are not suitable for the Indonesian people. However, if it does not immediately break away from the colonial law, the national legal system based on Pancasila will not be fully formed, because there will always be the shadow of colonialism in it.

Especially from a historical point of view, Code of Civil Law is actually not for Indonesian citizens[23], because at the beginning of its implementation in Indonesia, Code of Civil Law was intended for the European group (or its equivalent) and Chinese people who submitted to Code of Civil Law. In the end Indonesia adopted the Code of Civil Law to fill the existing legal vacuum. But now, Indonesia has developed in such a way as to be far more advanced than before. Indonesia has been able to make its own rules, and slowly break away from colonial rules, as is done in the Agrarian Law and Marriage Law.

Basically Law No. 13/2003 on the elucidation section of the law [24], it has realized that labor regulations that have been in force so far, including some that are colonial products, place workers at a disadvantage in the employment services and system industrial relations that emphasizes differences in position and interests so that they are no longer in accordance with current needs and demands of the future. Reflecting on this spirit, it should be done not only partial revocation of labor regulations in the colonial era, but as a whole including the revocation of working conditions in Code of Civil Law.

If the relevant articles are found, the provisions in the article can be adopted in the existing Manpower Law. The advantage is that the Manpower Act can expressly revoke the work provisions contained in Code of Civil Law. This also helps to clarify the position of Code of Civil Law in Indonesia, so that it will gradually become pure literature.

\section{Conclusion}

Indonesia should free itself from colonial legislation and slowly develop its own national law, one of which is in the field of labor, because the best civil law is the philosophy of Pancasila, and has philosophical foundations based on the views and personality of the Indonesian people by promoting the principles - basic principles of justice, truth and legal certainty. For this to happen, Law No. 13/2003 should be revised, and the revision is certainly in the better direction, because it cannot be denied that there are things that are better regulated in the civil law books than Law No.13 / 2002. As for the addition of the contents that must be done are: a) the employment agreement between husband and wife, b) the provisions of the fine along with compensation, c) the obligation of the employer to pay wages on time, d) the obligation of the employer to provide a certificate of 
employment to the worker and make it with without lies, and e) arrangements regarding responsibility and compensation in the chartering of work.

\section{References}

[1] A. A. Putu, W. Sugiantari, and M. H. Dosen, "PERKEMBANGAN HUKUM INDONESIA DALAM MENCIPTAKAN UNIFIKASI DAN KODIFIKASI HUKUM Oleh," 109 Jurnal Advokasi, vol. 5, no. 2, pp. 109-122, 2015, Accessed: Jun. 16, 2020. [Online]. Available: https://media.neliti.com/media/publications/29392-ID-perkembanganhukum-indonesia-dalam-menciptakan-unifikasi-dan-kodifikasi-hukum.pdf.

[2] S. Hartono, "Analisa dan Evaluasi Peraturan Peraturan Perundang-Undangan Peninggalakan Kolonial Belanda," Jakarta, 2015. Accessed: Jun. 16, 2020. [Online]. Available: https://www.bphn.go.id/data/documents/ae_peraturan_perundangundangan_peninggalan_kolonial_belanda.pdf.

[3] R. S. E. A. P. Magnis Florencia Butar- Butar*, "PENERAPAN DOKTRIN PROMISSORY ESTOPPEL DALAM PEMENUHAN PRESTASI SEBAGAI AKIBAT ADANYA PERJANJIAN ANJAK PIUTANG DI INDONESIA," Diponegoro Law Journal, vol. 6, no. 2, pp. 1-20, Apr. 2017, Accessed: Jun. 16, 2020. [Online]. Available: https://ejournal3.undip.ac.id/index.php/dlr/article/view/19576.

[4] S. al Fatih, "Kata Sepakat Dalam Perjanjian Dan Relevansinya Sebagai Upaya Pencegahan Wanprestasi," DE LEGA LATA: Jurnal Ilmu Hukum, vol. 5, no. 1, pp. 57-66, Jan. 2020, doi: 10.30596/dll.v5i1.3446.

[5] E. Hariyanto, "BURGELIJK WETBOEK (Menelusuri Sejarah Hukum Pemberlakuannya di Indonesia)," Al-Ihkam: Jurnal Hukum dan Pranata Sosial, vol. 4, no. 1, pp. 140-152, 2013, doi: 10.1111/jth.12638.

[6] I. Soerodjo, “The Development of Indonesian Civil Law," Scientific Research Journal (SCIRJ), vol. 6, no. 9, p. 35, 2016, Accessed: Mar. 06, 2020. [Online]. Available: http://www.scirj.org/papers-0916/scirj-P0916357.pdf.

[7] R. Marbun, A. Hakim, and M. A. Sunggara, "Legal Philosophy of Pancasila as The Paradigm of The Criminal Justice System: A Philosophical Criticism for the Loss of a Sense of Humanity," SHS Web of Conferences, vol. 54, pp. 1-6, 2018, doi: 10.1051/shsconf/20185407001.

[8] Y. Sezgin and M. Künkler, "Regulation of religion and the religious: The politics of judicialization and bureaucratization in India and Indonesia," Comparative Studies in Society and History, vol. 56, no. 2, pp. 448-478, 2014, doi: 10.1017/S0010417514000103. [9] M. Noor, "Unifikasi Hukum Perdata dalamPluralitas Sistem Hukum Indonesia," MAZAHIB, vol. 13, no. 2, pp. 115-124, 2014, Accessed: Mar. 06, 2020. [Online]. Available: https://media.neliti.com/media/publications/57818-ID-unifikasi-hukum-perdata-dalampluralitas.pdf. 
[10] Martitah, "REFORMA PARADIGMA HUKUM DI INDONESIA DALAM PERSPEKTIF SEJARAH," Paramita: Historical Studies Journal, vol. 23, no. 2, pp. 179192, 2013, doi: 10.15294/paramita.v23i2.2668.

[11] T. A. Christiani, "Normative and Empirical Research Methods: Their Usefulness and Relevance in the Study of Law as an Object," Procedia - Social and Behavioral Sciences, vol. 219, no. 1, pp. 201-207, May 2016, doi: 10.1016/j.sbspro.2016.05.006.

[12] A. M. Aji, M. I. Helmi, and N. R. Yunus, "The Ministerial Regulation Position in the Hierarchy of Legislation in the Indonesian Legal System," International Journal of Advanced Science and technology, vol. 29, no. 02, pp. 2214-2224, 2020, [Online]. Available: http://sersc.org/journals/index.php/IJAST/article/view/3641/2503.

[13] G. van Klinken, "Citizenship Studies Citizenship and local practices of rule in Indonesia Citizenship and local practices of rule in Indonesia," Citizenship Studies, vol. 22, no. 2, pp. 112-128, 2018, doi: 10.1080/13621025.2018.1445489.

[14] M. Vink, "“The World's Oldest Trade': Dutch Slavery and Slave Trade in the Indian Ocean in the Seventeenth Century," Journal of World History, vol. 14, no. 2, pp. 131-177, 2003, doi: 10.2307/20079204.

[15] L. Arliman, "Perkembangan dan Dinamika Hukum Ketenagakerjaan di Indonesia," Jurnal Selat, vol. 5, no. 1, pp. 74-86, 2017, [Online]. Available: http://ojs.umrah.ac.id/index.php/selat/article/download/215/252.

[16] F. Amalia Fathimah, "The Extractive Institutions as Legacy of Dutch Colonialism in Indonesia," Uppsala, 2018. Accessed: Jun. 22, 2020. [Online]. Available: http://www.teknik.uu.se/student-en/.

[17] Ilyas and Dkk, Pengantar Hukum Indonesia. Aceh: CV Bina Nangroe Aceh, 2012.

[18] Subijanto, "Peran Negara Dalam Hubungan Tenaga Kerja di Indonesia," Jurnal Pendidikan dan Kebudayaan, vol. 17, no. 6, pp. 705-718, 2011, [Online]. Available: http://jurnaldikbud.kemdikbud.go.id/index.php/jpnk/article/viewFile/61/58.

[19] R. A. C. Naldo and M. Purba, "Pemikiran FIlsafat Hukum Ke Arah Kepribadian Bangsa," Jurnal Ilmiah Advokasi, vol. 06, no. 01, pp. 42-55, 2018, doi: https://doi.org/10.36987/jiad.v6i1.263.

[20] Sulardi and F. Esfandiari, "The Authority of the People's Consultative Assembly and the Discourse of the Limited Amendment of the Constitution," May 2020, pp. 244-248, doi: 10.2991/aebmr.k.200513.050.

[21] M. Maroni, "Problema Penggantian Hukum-Hukum Kolonial Dengan Hukum-Hukum Nasional Sebagai Politik Hukum,” Jurnal Dinamika Hukum, vol. 12, no. 1, pp. 85-96, 2012, doi: 10.20884/1.jdh.2012.12.1.199.

[22] S. Bombang, S. Haling, H. Husainy, P. Halim, and A. Rahim, "Quo Vadis: Can Indonesia survive without Pancasila?," International Journal of Innovation, Creativity and Change. www.ijicc.net, vol. 8, no. 12, pp. 387-397, 2019, Accessed: Jun. 22, 2020. [Online]. Available: www.ijicc.net. 
[23] I. Soerodjo, "The Development of Indonesian Civil Law," Scientific Research Journal (SCIRJ), vol. IV, no. IX, p. 30, 2016, Accessed: Jun. 22, 2020. [Online]. Available: www.scirj.org.

[24] P. N. Hidayah, "Comparative Study of Legal Protection for Migrant Workers In Participation Of Social Security Programs In Indonesia And Singapore," Legality: Jurnal Ilmiah Hukum, vol. 28, no. 1, pp. 47-59, Apr. 2020, doi: 10.22219/ljih.v28i1.11786. 